\title{
Yeni Tanı Primer Biliyer Kolanjitli Hasta: Olgu Sunumu
}

\section{Newly Diagnosed Patient with Primary Biliary Cholangitis: Case Report}

\author{
$\underline{\text { Nuray KIVANCC TERZI }}^{1}{ }^{(D)}$, Mehmet Sidar GÜLER ${ }^{2}{ }^{(\mathbb{D})}$, Dursun ÇADIRCI ${ }^{1}{ }^{(\mathbb{D})}$, Ahmet UYANIKOĞLU ${ }^{3}$
}

\begin{abstract}
1 Harran Üniversitesi Tıp Fakültesi, Aile Hekimliği Anabilim Dalı, Şanlıurfa,Türkiye
2 Harran Üniversitesi Tıp Fakültesi, İç Hastalıkları Anabilim Dalı, Şanlıurfa,Türkiye

3 Harran Üniversitesi Tıp Fakültesi, Gastroenteroloji Bilim Dalı, Şanlıurfa,Türkiye
\end{abstract}

\section{Öz.}

Primer biliyer kolanjit (PBK) etiyolojisi bilinmeyen, çoğunlukla orta yaş kadınların etkilendiği, küçük safra kanallarında hasarın eşlik ettiği, yavaş ilerleyen, kronik kolestatik granülomatöz bir karaciğer hastalığıdır. PBK, portal hipertansiyon veya karaciğer yetmezliği gibi ciddi hastalıklara neden olup sonrasında siroza ilerleyebilir. Bu vakada olduğu gibi non-spesifik semptomlarla gelebileceği unutulmamalı, ayrıntılı anamnez ve şüphelenilen hastalarda gerekli laboratuvar tetkikleri ile tanı kesinleştirilmelidir.

Anahtar kelimeler: Primer biliyer kolanjit, Antimitokondriyal antikor, Kaşıntı

\section{Abstract}

Primary biliary cholangitis (PBC) is a slowly progressive chronic cholestatic granulomatous liver disease of unknown etiology, mostly affected by middle-aged women, accompanied by damage to the small bile ducts. PBK can cause serious diseases such as portal hypertension or liver failure and then progress to cirrhosis. As in this case, it should not be forgotten that it may come with non-specific symptoms, detailed history and diagnosis should be confirmed with necessary laboratory tests in patients suspected.

Keywords: Primary biliary cholangitis, Antimitochondrial antibody, Itching
Sorumlu Yazar I

Corresponding Author

Arş. Gör. Dr. Nuray KIVANÇ TERZI

Harran Üniversitesi Tıp Fakültesi, Aile Hekimliği ABD,

Osmanbey Kampüsü

Haliliye / Şanlıurfa

Tel: 05464644672

E-mail: dr.nryterzi@gmail.com

Geliş tarihi / Received:

07.05.2020

Kabul tarihi / Accepted:

18.12.2020

DOI: $10.35440 /$ hutfd. 733455

16.Anadolu Gastroenteroloji Günleri'nde sözlü bildiri olarak sunulmuştur. 


\section{Giriş}

Primer biliyer kolanjit (PBK) en sık görülen kolestatik karaciğer hastalıklarından biridir (1). Küçük safra kanallarında hasar meydana getiren ve kronik granülomatöz olarak ilerleyen bir yapıya sahiptir (2). Genetik yatkınlık ve çevresel faktörler suçlanan nedenler arasında olsa da etiyoloji halen tam olarak bilinmemektedir. Çevresel faktörler arasında oje, ksenobiotikler ve sigara sayılabilir (1).

PBK, sıklıkla orta yaş kadınlarda görülür ve kadınlar erkeklere oranla 9 kat daha fazla etkilenir. Avrupa'nın kuzey kesimlerinde daha yaygın görülmekle birlikte, en az görülen bölge olarak Afrika bilinmektedir. Hastalığın insidansı 0.33$5.8 / 100.000$, prevalansı ise $1.9-40 / 100.000$ olarak bildirilmiştir $(3,4)$.

PBK'nin yavaş ilerlediği bilinmekle beraber şiddeti değişkenlik gösterebilir (5). Genç hastalar (40 yaş altı tanı konulmuş) siroza doğru daha hızlı bir ilerleme eğilimi göstermektedirler (6). Genel itibari ile de tedavi edilmeyen hastalar 10 ile 20 yıl arasında siroz ve karaciğer yetmezliğine ilerleyebilmektedir $(1,6)$. Yapılan bir çalışmada, semptom gösterme oranları ve yaşam süresi değerlendirilmiş, semptomatik hastalarda ortalama yaşam süresi 7.5 yıl bulunmasına karşın, asemptomatik hastalar için bu süre 16 yıl olarak bildirimiştir (1). Halsizlik, yorgunluk ve kaşıntı gibi semptomlar görülebilen bu hastalığa, kutanözkalsinoz, Raynaud fenomeni ve sicca sendromu gibi immünolojik bozukluklar eşlik edebilir (4).

Tedavide ise ursodeoksikolik asit (UDCA) halen önemini sürdürmekte ve PBK'lı hastalar için uzun süreli nakilsiz sağkalım sağlamaktadır. UDCA ya cevap vermeyenler için ise tedavi seçenekleri sınırlı kalmıştır (1).

$\mathrm{Bu}$ olgu sunumundaki amacımız çok yaygın görülmeyen, non-spesifik semptomlardan maligniteye kadar ilerleyebilecek bu hastalığın, semptomatik olsa bile geç tanı alabileceğini vurgulamaktır.

\section{Olgu Sunumu}

39 yaşındaki kadın hasta, epigastrik bölgede ağrı, kaşıntı, halsizlik ve yorgunluk şikayetleri ile üniversitemizin gastroenteroloji polikliniğine başvurdu. Hastanın şikayetlerinin yaklaşık 5 yıldır olduğu, çeşitli polikliniklere başvurduğu ve karaciğer enzim yüksekliğinden dolayı karaciğerinde yağlanma düşünüldüğü öğrenildi. Öz geçmişinde ve soy geçmişinde özellik bulunmayan hastanın fizik muayenesi normaldi. Kan tetkiklerinde hemogram normal, Aspartataminotransferaz (AST): $83 \mathrm{U} / \mathrm{L}$ (normal değerler: 5-35 U/L), alaninaminotransferaz (ALT): $69 \mathrm{U} / \mathrm{L}$ (normal değerler: 5$40 \mathrm{U} / \mathrm{L}$ ), alkalenfosfataz (AF): $632 \mathrm{U} / \mathrm{L}$ (normal değerler: 90-260 U/L), gama-glutamil-transferaz (GGT): $622 \mathrm{U} / \mathrm{L}$ (normal değerler: $7-32 \mathrm{U} / \mathrm{L}$ ), total bilirubin: $0.5 \mathrm{mg} / \mathrm{dl}$, protein elektroforezinde gama globulin hafif artmıştı: $2.11 \mathrm{~g} / \mathrm{dl}$ (normal 0.60-1.5 g/dl), \%24.1 (normal \% 9.5-20.7) olarak bulundu. Otoimmün belirteçlerden antinükleer antikor
(ANA) ve antimitokondriyal antikor (AMA) pozitif olan hastanın yapılan ultrasonografisinde, karaciğer parankimi ince granüler görünümdeydi. Mevcut bulgularla hastaya PBK teşhisi konuldu, $15 \mathrm{mg} / \mathrm{kg}$ ursodeoksikolik asit tedavisi başlandı ve kontrolleri planlandı. Hastanın sonraki ziyaretlerinde semptomlarının azaldığı, laboratuvar parametrelerinin gerilediği gözlendi.

\section{Tartışma}

Intrahepatik safra yollarının ilerleyici hasarı ile karakterize bu hastalık için "primer biliyer siroz" halen popüler bir tanım olsa da "kronik non-süpüratif destrüktif kolanjit" yada primer biliyer kolanjit" te bu hastalığı tanımlamak için kullanılan isimler arasındadır (7).

Bu hastalık, 30-65 yaş aralığındaki (ortalama 39) kadınları daha çok etkiler (3). Bu olgunun da yaşı ve cinsiyeti literatür ile uyumludur. PBK olguları çoğunlukla karşımıza asemptomatik (\%50-60) çıkabilmektedir (3). Semptomatik olan hastalarda ise en sık olarak halsizlik-yorgunluk (\%65) şikayeti karşımıza çıkmaktadır. Kaşıntı $(\% 55)$ geç ortaya çıkan bir bulgudur. Özellikle gebelikte başlayabilir. Sıcaklık, yün maruziyeti ile şiddetlenebilir ve geceleri artış gösterebilir (3). Kaşıntıya, dolaşımdaki safra tuzları, opioiderjik moleküller ve diğer metabolitlerin neden olabileceği öne sürülmüştür (8).

Bizim olgumuzda da hasta bu gibi (yorgunluk, halsizlik v.b.) non-spesifik semptomlar ile çeşitli merkezlere başvurmuş ve geç tanı almasının nedenlerinden birisi de yine bu nonspesifik semptomlar olmuştur.

Karaciğer enzim yüksekliği, biliyer görüntüleme ve AMA antikor pozitifliği teşhis için gerekli parametrelerdir (9). PBK için spesifik olan AMA, \%90-95 oranında duyarlıığa sahiptir. Tanı için karaciğer biyopsisi gerekli değildir, ancak kesin tanı konulamayan, şüphede kalınan hastalarda (AMA nın negatif olması gibi) etkin bir tanı yöntemi olarak değerlendirilebilir (4). Olgumuzda klinik olarak kaşıntı olması, biyokimya bulgularında ön planda kolestaz enzimler yüksek ve seroloji (AMA) pozitif olduğu için biyopsiye gerek görülmemiştir. ANA pozitifliği de mevcut olan hastanın ayırıcı tanısında overlap sendromuna dikkat edilmelidir. Tanı için otoimmün hepatit özellikleri ile PBK bulgularının beraber seyretmesi ve tedaviye yanıtsızlık olması gerektiği unutulmamalıdır $(3,6,7)$. Bu vakada otoimmün hepatit skoru 10 puanın altında olduğundan ve tedaviye uygun yanıt alındığından overlap sendromu düşünülmemiştir.

PBK, yavaş ilerleyen bir hastalıktır ancak aynı yaş ve cinsiyetteki kontrol grubu ile karşılaştırıldığında yaşam süresi anlamlı olarak daha az bulunmuştur (10). Yine bu hastalarda artmış malignite riski, özellikle lenfoproliferatif maligniteler söz konusudur $(11,12)$.

1980 li yıllarda PBK'I' hastalar için tek tedavi kaynağı karaciğer nakli iken UDCA'nın kullanılması PBK tarihinde önemli bir dönüm noktası olmuştur. Yıllarca süren tartışmalardan sonra, fikir birliğine varılmış ve UDCA standart 
tedavi olarak kabul edilmiştir. UDCA, özellikle hastalı̆̆ın erken döneminde başlandığında, nakilsiz sağkalımı artırdığı yapılan çalısmalarda gösterilmiştir (5). Alternatif yeni tedaviler çıkmasına rağmen, UDCA halen PBK için birinci basamak tedavi olmayı sürdürmektedir.

PBK, portal hipertansiyon veya karaciğer yetmezliği gibi ciddi hastalıklara neden olabilmekte ve sonrasında siroza ilerleyerek ölüme yol açabilmektedir. Bizim hastamızda olduğu gibi non-spesifik semptomlarla gelebileceği unutulmamalı, ayrıntılı anamnez ve şüphelenilen hastalarda gerekli laboratuvar tetkikleri istenmeli, özellikle otoimmun belirteçler unutulmamalı ve tanı kesinleştirilmelidir.

\section{Hasta onamı: Çalışma için hastadan yazılı onam alınmış- tir.}

\section{Kaynaklar}

1. Santiago P, Scheinberg AR, Levy C. Cholestatic liver diseases: new targets, new therapies. Therapeutic Advances in Gastroenterology. 2018;11(1):1-15.

2.Gershwin ME, Mackay IR. The causes of primary biliary cirrhosis: convenient and in convenient truths. Hepatology. 2008;47(2):737-745. 3. Tkcv.org [homepage on the Internet]. Primer biliyer kolanjit (Primerbiliyer siroz) Türkiye-Azerbaycan Ortak Hepatoloji Kursu [updated 29 Eylül 2017; cited mart 2020] Available from: www.tkcv.org

4. Malik A, Kardashian AA, Zakharia K, Bowlus CL, Tabibian JH. Preventative care in cholestatic liver disease: Pearls for the specialist and subspecialist. LiverResearch. 2019;3(2):118-127.

5.Corpechot C, Poupon R, Chazouilleres O. New treatments / targets for primary biliary cholangitis. JHEP Reports. 2019;1(3):203-21.

6.Culp KS, Fleming CR, Duffy J, Baldus WP, Dickson ER. Autoimmune associations in primary biliary cirrhosis. Mayo Clin Proc. 1982;57(6):365-370.

7. Palabıyıkoğlu M. Primer Biliyer Siroz. Turkiye Klinikleri Journal of Microbiology Infection. 2003;2(3):166-172.

8.Ghent CN, Bloomer JR, Klatskin G. Elevations in skin tissue levels of bile acids in human cholestasis: relationto serum levels and to pruritus. Gastroenterology. 1977;73(5):1125-1130.

9. Tekin F, Görümlü G, Yüce G, Soydan S, Özütemiz Ö, IIter T. Multipl myelom ve primer biliyer siroz birlikteliği: Olgu sunumu. Akademik Gastroenteroloji Dergisi. 2008;7(2):111-113.

10. Christensen E, Crowe J, Doniach D, Popper H, Ranek L, Rodes J, et al. Clinical pattern and course of disease in primary biliary cirrhosis based on analysis of 236 patients. Gastroenterology. 1980; 78(2):23646.

11. Nijhawan PK, Therneau TM, Dickson ER, Boynton J, Lindor K D. Incidence of cancer in primary biliary cirrhosis: the Mayo experience. Hepatology. 1999; 29(5):1396-1398.

12. Goudie BM, Burt AD, Boyle P, Macfarlane G, Birnie GG, Mills PR, et al. Breast cancer in women with primary biliary cirrhosis. BMJ 1985; 291(6509):1597-1598. 